\title{
A HLD ÉRTÉK KŐOLAJIPARI ALKALMAZHATÓSÁGA
}

\section{APPLICATION OF THE HLD VALUE IN THE PETROLEUM INDUSTRY}

\author{
Nagy Roland ${ }^{1}$, Lendvai Péter ${ }^{2}$, Kothencz Réka ${ }^{3}$, Bartha László ${ }^{4}$ \\ ${ }^{1}$ Pannon Egyetem, Mérnöki Kar, MOL Ásványolaj- és Széntechnológiai Intézeti Tan- \\ szék, Magyarország, Veszprém, Egyetem u. 10, Telefon: +3688/624-000/6175, \\ nroland@almos.uni-pannon.hu \\ ${ }^{2}$ Pannon Egyetem, Mérnöki Kar, MOL Ásványolaj- és Széntechnológiai Intézeti Tan- \\ szék, Magyarország, Veszprém, Egyetem u. 10, Telefon: +3688/624-000/6175, \\ peti.lendvai1993@gmail.com \\ ${ }^{3}$ Pannon Egyetem, Mérnöki Kar, MOL Ásványolaj- és Széntechnológiai Intézeti Tan- \\ szék, Magyarország, Veszprém, Egyetem u. 10, Telefon: +3688/624-000/6175, \\ kothenczr@almos.uni-pannon.hu \\ ${ }^{4}$ Pannon Egyetem, Mérnöki Kar, Magyarország, Veszprém, Egyetem u. 10, Telefon: \\ +3688/624-305, bartha@almos.uni-pannon.hu
}

\begin{abstract}
The efficiency of demulsification is a key process in terms of extracting the oil of $\mathrm{O} / \mathrm{V}$ (oil-in-water type) emulsions of enhanced oil recovery. Consequently, the separation of emulsion systems and the recovery of the maximum amount of oil of the colloid system play an important role in petroleum industry. The stability of the emulsions from oil recovery is influenced by numerous factors. J.L. Salager has developed the HLD (Hydrophilic-Lipophilic Deviation) equation in order to examine the efficiency of demulsification. Our aim was to investigate whether the equation developed by Salager is suitable for monitoring the stability of petroleum industrial emulsions.
\end{abstract}

Keywords: enhanced oil recovery, demulsification, $H L D$ value.

\section{Összefoglalás}

A harmadlagos kőolajkitermelés során keletkező főleg $O / V$ (olaj a vízben típusú) emulziók olajtartalmának kinyerése céljából a demulgeálás folyamatának hatékonysága kulcsfontosságú. Következésképp a harmadlagos kőolajkitermelés során keletkezett emulziós rendszerek szétválasztásának vizsgálata, és a kolloid rendszer olajtartalmának a lehető legnagyobb arányú kinyerése fontos szerepet játszik a kőolajiparban. Az így keletkezett emulziók stabilitását számos tényező befolyásolja. A demulgeálás hatékonyságának vizsgálata során a J.L. Salager által kidolgozott HLD (Hidrofil-Lipofil Eltérés) egyenletet alkalmaztuk. Megvizsgáltuk, hogy a Salager által kidolgozott egyenlet alkalmas-e kőolajipari emulziók stabilitásának nyomon követésére.

Kulcsszavak: harmadlagos köolajkitermelés, demulgeálás, HLD érték. 


\section{Bevezetés}

A különböző ipari technológiák ma már nem nélkülözhetik az emulziók alkalmazását. A diszperz rendszerek meghatározóak az iparban, illetve a különböző életfolyamatokban. Az emulgeálás és az emulziók bontási folyamata fontos szerepet játszik abban, hogy az emulziót létrehozni vagy megbontani szeretnénk [1,2].

A demulgeálási müveletek során különböző paraméterek befolyásolják a diszperz rendszerek stabilitását. Ezek a paraméterek a következők lehetnek: sótartalom, hőmérséklet, pH, víz és olaj fázis összetétele, aggregációs sebesség és időtartam, emulgeálószer vagy demulgeálószer koncentráció, részecske méret és eloszlása [3].

A kőolajipari demulgeálás során a nyers kőolajat kívánjuk elválasztani a vizes fázistól. A diszperz rendszerek demulgeálása során különböző mechanizmusú folyamatok mehetnek végbe, amelyek illusztrációját az 1. ábra tartalmazza [4].

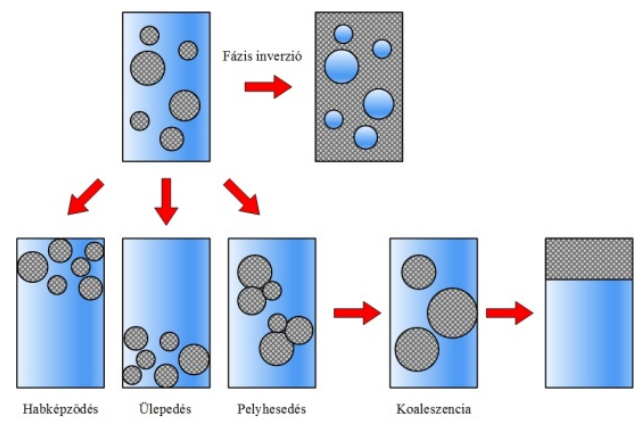

1. ábra. A demulgeálás során lejátszódó folyamatok

Az emulziók megbontásának legelterjedtebb módja a demulgeálószer hozzáadása a diszperz rendszerhez. Ennek során különböző sók (például alumínium vagy vas-sók) hozzáadása is lehetséges a kolloid rendszerhez [5]. A kőolajiparban előforduló $\mathrm{O} / \mathrm{V}$ diszperz rendszereknél alkalmazott kémiai demulgeálószerek elsődleges felada- ta a kőolaj lehető legnagyobb mennyiségének kinyerése.

Célunk a szénhidrogén kitermelés során felszínre került $O / V$ emulziók szétválasztásának, illetve a HLD érték alkalmazhatóságának vizsgálata volt. Továbbá azt kívántuk megvizsgálni, hogy a HLD érték alkalmas-e a demulgeálás folyamatának nyomon követésére.

\section{A HLD érték definiálása}

J. L. Salager általánosította a termodinamikai eredetü felületaktív affinitás különbség (SAD) egyenletét, mely segítségével könnyebben jellemezhetőek a makro-, illetve mikroemulziós rendszerek. Ezt az empirikus korrelációt jellemző értékszámot HLD-nek (Hydrophilic Lipophilic Deviation) nevezzük, ami egy dimenziómentes egyenlettel számítható, amelyet alkalmasnak találtak az emulziók stabilitásának jellemzésére. A HLB-vel ellentétben, amely csak a tenzidet veszi figyelembe, a HLD egyenlet magába foglalja a legtöbb stabilitást befolyásoló tényezőt, mint például a felületaktív anyagok és olajos fázis tulajdonságai, valamint a sótartalom és só koncentráció, a hőmérséklet, illetve a nyomás [6,7].

$\mathrm{Az}$ ionos felületaktív anyagokat is tartalmazó $O / V$ típusú emulziók HLD értéke általában negatív. Az emulzió akkor a legkevésbé stabil, ha a HLD értéke a nullához közelít, mivel ebben az esetben nincs eltérés a hidrofil és lipofil kölcsönhatások között. Ezt a demulgeálószerek segítségével tudjuk befolyásolni. A vizsgálatok során kiderült, hogy a demulgeálószer koncentrációja a vártnál jobban befolyásolja a stabilitást. Optimálisnál kisebb koncentráció esetén értelemszerüen a tenzid nem képes a felületaktív filmréteg felszakítására. Abban az esetben viszont, ha az optimálisnál nagyobb demulgeálószer koncentrációt alkalmazunk, ellenkező hatást elérve sokkal sta- 
bilabbá tehetjük a bontani kívánt emulziót $[6,7]$.

Alapvetően a HLD egyenletnek két formáját dolgozták ki, egyik azokat a rendszereket jellemzi, ahol a tenzidek nemionosak (1), másik eset mikor ionosak (2) [8].

$$
\begin{aligned}
& H L D=\alpha-E O N+b(\text { só })-k A C N+ \\
& t \triangle T+a A
\end{aligned}
$$

$H L D=\sigma+\ln (s o ́)-k A C N+t \Delta T+a A$

ahol:

EON: etoxilezett nemionos felületaktív anyagok „etilén-oxid” csoportjainak száma

só: sótartalom a $\mathrm{NaCl}$-ra vonatkoztatott tömegszázalékban kifejezve

ACN: a tenzidmolekula n-alkil láncának szénatomszáma,

$\Delta \mathrm{T}$ : hömérsékletkülönbség a referencia hömérséklethez képest $\left(25^{\circ} \mathrm{C}\right)$,

A: hozzáadott alkohol mennyisége tömegszázalékban kifejezve,

$\sigma, \alpha, \mathrm{k}, \mathrm{t}$ : az alkalmazott tenzidekre jellemző paraméterek,

a: az alkoholra és a tenzidre jellemző konstans,

b: a hozzáadott sóra jellemző konstans.

A HLD tehát egy átfogó koncepció szerinti számítások eredménye, amely magába foglalja az összes fontosabb fizikai-kémiai tulajdonságot, mellyel könnyebb elöre jelezni az egyes változók hatását. Az egyenlet valamennyi paramétere könnyen és gyakorlatilag számszerüsíthetö.

\section{A HLD érték kőolajipari alkal- mazhatósága}

A harmadlagos kőolaj-kitermelés egyik típusának alkalmazása során a felhasznált nagy felületaktív hatékonyságú tenzidek a rétegvízzel és a kőolajjal emulziót képeznek, eközben csökkentik a határfelületi feszültséget és így az olajrészecskéket a póru- sokon keresztül kimossák, majd a belöle képződött emulzió a termelőkúton távozik.

Vizsgálataink során a HLD érték alkalmazhatóságát kívántuk meghatározni különböző típusú demulgeálószerek felhasználása esetén.

A HLD értéket elöször egy modell emulzióra vonatkoztatva számítottuk ki, amely tenzidek (kókusz-zsírsav-DEA, DBS-Na), butoxietanol $(0,6 \mathrm{~m} / \mathrm{m} \%)$, modell olaj (95 V/V\%) és modell rétegvíz (5 V/V\%) felhasználásával történt. A mérések során egy polivalens sónak, egy nagy szénatomszámú lineáris alkoholnak és egy tenzidnek (etoxilált származék) valamint különböző demulgelószereknek a hatását vizsgáltuk különböző koncentrációban történő alkalmazás esetén.

A standardemulzió HLD értékéhez a következő egyenletet alkalmaztuk:

$H L D=\left(x_{i} * \alpha_{i}+x_{i} * \sigma_{i}\right)+\sum x_{i} \ln \left(s o_{i}\right)-$

$\sum x_{i} k_{i} A C N+t \Delta T+a A$

ahol:

só: sótartalom tömegszázalékban kifejezve

ACN: az tenzidmolekula n-alkil láncának átlagos szénatomszáma

$\Delta \mathrm{T}$ : hőmérsékletkülönbség a referencia hőmérséklethez képest $\left(25^{\circ} \mathrm{C}\right)$

A: hozzáadott alkohol mennyisége tömegszázalékban kifejezve

$\sigma, \alpha, \mathrm{k}, \mathrm{t}$ : az alkalmazott tenzidekre jellemző paraméterek

a: az alkoholra és a tenzidre jellemző konstans

x: egyes komponensek móltörtjei

A fenti egyenletekbe behelyettesítve a standardemulzió demulgeálószer-mentes HLD értékeként -5,94 adódott. Mivel a HLD érték negatív előjelü lett, egy $\mathrm{O} / \mathrm{V}$ diszperz rendszer valószínüsíthető [8], ezt korábban végzett, reológiai vizsgálataink is igazolták [9]. Az érték nagysága pedig megmutatja, hogy ez a rendszer igen nagy stabilitással bír. 
A polivalens sót, a nagy szénatomszámú lineáris alkoholt és a tenzid (etoxilált származék) demulgelószereket különböző koncentrációkban adtuk a modell emulzióhoz, majd minden esetben kiszámoltuk a HLD értékeket.

Az alkalmazott demulgeálás hatásának eredményeit a 2. ábrán hasonlítottuk össze.

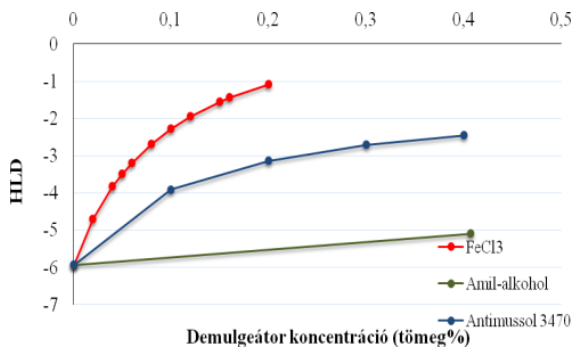

2. ábra. Az alkalmazott háromféle demulgeálószer HLD értékeinek a változása az alkalmazott mennyiségek függvényében

Az 2. ábra alapján jól látható, hogy a polivalens só alkalmazása esetén sokkal kisebb koncentráció is elegendő a kívánt hatás eléréséhez. A másik két demulgeálószer lényegesen csökkentette az emulzió stabilitását, viszont a feleslegben alkalmazott mennyiségük szintén a polivalens só előnyeit támasztják alá.

A demulgeálás hatékonyságának a vizsgálatára bevezettük az un. DF, demulgeálási faktor értéket, mely a leválasztott olaj/ eredeti olaj mennyiség hányadosa (1. táblázat).

1. táblázat. A demulgeálási faktor nagysága különbözö típusú demulgeátorok esetén

\begin{tabular}{|l|c|c|}
\hline Demulgeátor típusa & $\begin{array}{c}\text { Demulgeátor } \\
\text { koncentráció }\end{array}$ & DF \\
\hline Polivalens só & 0,2 tömeg\% & 1 \\
\hline $\begin{array}{l}\text { Nagy szénatomszámú } \\
\text { lineáris alkohol }\end{array}$ & 0,2 tömeg\% & 0,9 \\
\hline Etoxilált származék & 0,2 tömeg\% & 0,85 \\
\hline
\end{tabular}

Az eredmények alapján megállapítottuk, hogy a HLD összefüggés alkalmas a sók, az alkoholok, valamint a többféle tenzidet tar- talmazó emulziók bonthatóságának jellemzésére. Az egyes alkalmazott demulgeálószer koncentrációknál végig követhető a diszperz rendszer stabilitásának csökkenése. Az alkalmazott demulgeálószerek különböző mértékben csökkentették a kolloid rendszer stabilitását.

\section{Következtetések}

A HLD értékek számítása esetén bemutattuk, hogy az összefüggés alkalmas lehet a polivalens sók, alkohol és tenzid típusú demulgeálószer alkalmazása során a diszperz rendszer stabilitás változásának előzetes jellemzésére. A különböző sótartalmú vegyületek kombinálása szerves, és/vagy polimer vegyületekkel pedig növelhetik az olajkinyerés hatékonyságát az O/V típusú emulziók esetén.

\section{Szakirodalmi hivatkozások}

[1] Schramm, L.L.: Emulsions, Foams, and Suspensions: Fundamentals and Applications. Wiley, Calgary, 1992.

[2] Becher, P.: Emulziók, Müszaki könyvkiadó, Budapest, 1965.

[3] Möbius, D., Miller, R., Fainerman, V.B.: Surfactants: Chemistry, Interfacial Properties, Applications, Elsevier, Amsterdam, 2001.

[4] Rajakovic, V. et al: Separation of water-inoil emulsions by freeze/thaw method and microwave radiation, Sep. Purif. Technol, 49, 2006, 192-196.

[5] Daniel, J.F: The Nalco Water Handbook, Nalco Company, Third Edition, chapter 11 Emulsion Breaking, 2009.

[6] Salager, J.L.: Microemulsions, in: Broze, G.: Handbook of Detergents, Marcel Dekker, New York, 1999.

[7] Salager, J.L.: Emulsion phase inversion phenomena, in: Sjöblom, J.: Emulsions and emulsion stability, CRC Press, New York, 2006.

[8] Salager, J.L. et al: Formulation des microémulsions par la méthode du HLD, Techniques de l’Ingénieur, Génie des Procédés, 157, 2001, 1-20.

[9] Nagy, R., Elekes, A., Bartha L., Vágó, Á.: Rheological characterization of crude oilwater emulsions, Journal of Silicate Based and Composite Materials, 68, 2016, 98-104. 